\title{
3 Research Square

\section{Preparing the transition into long-term care institutions: a cluster analysis of the representations of the place of residence in European elders}

\section{Jan Chrusciel}

Centre Hospitalier de Troyes

Sofiane Zid

Centre Hospitalier de Troyes

Aude Letty

Fondation korian pour le bien vieillir

\section{Paul-Emile Hay}

Fondation korian pour le bien vieillir

\section{Didier Armaingaud}

Fondation korian pour le bien vieillir

\section{Moustapha Dramé}

Centre Hospitalier Universitaire de Martinique

\section{Lidvine Godaert}

Centre Hospitalier Universitaire de Martinique

Stéphane Sanchez ( $\nabla$ stephane.sanchez@ch-troyes.fr)

Fondation korian pour le bien vieillir https://orcid.org/0000-0002-0925-6948

Research article

Keywords: Aged person, Nursing home, Representation, Successful aging

Posted Date: October 31st, 2019

DOI: https://doi.org/10.21203/rs.2.16670/v1

License: (c) (i) This work is licensed under a Creative Commons Attribution 4.0 International License. Read Full License 


\section{Abstract}

Background: The risk of entry into a nursing home has been shown to vary according to geographical and clinical factors, although the effect of location could be due to confounders. The main objective of our study was to describe their perception of their place of residence in adults aged over 65 in four European countries.

Methods: The cross-sectional survey was carried out in February 2016 by a poll institute in a representative sample of individuals from a population of retired residents in four European countries, selected by quota sampling. A total of 4160 subjects aged 65 or older were selected. For descriptive analysis, qualitative variables were presented with absolute frequencies and percentages. A Principal Components Analysis was performed, and clusters were identified using results from the analysis.

Results: The study population comprised 4160 individuals from Germany, Belgium, France and Italy. Overall, 2389 (57\%) were women; 1414 (34\%) were aged 65 to 69, and $2709(65 \%)$ were living maritally. A majority $(2938,70 \%)$ were home owners, while $1253(30 \%)$ showed signs of social precariousness including low income, and 1159 (27\%) had a low level of education. Principal component analysis identified six well-defined groups: Wealthy Belgians, Flexible single people, Wealthy Germans, Lowincome Germans, Isolated Italians, Italian homebirds.

Conclusion : Understanding the representations that elderly Europeans have of their place of residence can help healthcare professionals decide how to assist each elder towards an acceptance of his/her new life in the nursing home.

\section{Introduction}

An estimated 728,000 persons live in the various residential care structures available for the elderly in France. The risk of entry into a nursing home has been shown to vary according to geographical and clinical factors $(1,2)$, although the effect of location could be due to confounders (3). A study realised in Florida suggests that the elderly from less populated, non-urban areas have a higher likelihood of being admitted to a nursing home (4). Entry into a nursing home is associated with a state of frailty, and a decrease in the social environment's ability to provide direct support (5-12), meaning life at home is no longer possible. The problem of caregiver burden is likely to increase in the years to come. The growing number of divorces, a decrease in natality (13) and a higher life expectancy are leading to a reduction in household size, which in turn reduces the potential number of caregivers $(14,15)$. These changes call for a re-evaluation of the current health policy regarding the elderly (16). There is no consensual definition of what "home" is. The concept of "home" covers physical and cognitive entities and is specific to each individual. The place where life is lived, one's "home" can extend beyond the walls of the house and include relations with loved ones and daily interactions. Indeed, it represents a mental space that is specific to each individual and built as a result of the events they experience in their life. It could be considered as the last outpost in which an individual takes refuge. Often, the decision to enter a nursing 
home is a default choice, because the person is no longer capable of living independently at home despite assistance. Nursing home entry is sometimes (17) not anticipated by the person, and often decided by their children and/or spouse. As cognitive impairment predicts entry in the nursing home (1820), cognitively impaired patients sometimes do not expect such a transition and can easily be disoriented in the process. Behavioural problems were also linked to institutionalization (21).

Nonetheless, caregivers are also often distressed when the patient enters long-term care, and as cognitive decline is frequent afterwards, they may be inclined to question their decision (22).

Thus, entering a nursing home can represent considerable mental trauma in addition to an increased financial strain (23). Moreover, this can happen in a context when the patient is experiencing depressive symptoms (24), which could make him less resilient. The older person transitions from a situation where they were in control, to a situation where they are a spectator, and everything is decided for them by others. Sometimes, short stays can precede long-term entry into a nursing home which could make the transition easier (25). A number of older people legitimately raise the question of the status of their private sphere, and the bridge between the individual and the collective. Caregivers can maintain continuity for the elder by visiting often. Frequent visits are associated with being a spouse, education, a strong sentiment against placement, proximity to the facility, a close past relationship before institutionalization (26).

An improved understanding among professionals of the psychological issues at play could help to facilitate a more empathic attitude and contribute to more harmonious development of a life project for nursing home residents. Although the definition of what constitutes successful aging is highly debated (27-30), satisfaction with the place of residence can also be studied using the theoretical frameworks of successful aging. For example, the Baltes model of Selection, Optimization and Compensation (SOC) could help us understand how new nursing home residents can reframe their perception of their place of residence and adopt new habits.

Therefore, the main objective of our study was to describe the perception of their residence in adults aged 65 years or older of four European countries. The secondary objective was to describe a model of representation for the elderly in each country, in order to better apprehend the characteristics specific to each participating nation.

\section{Materials And Methods}

\section{Study population}

The survey was carried out in February 2016 by a poll institute in a representative sample of individuals from the population of retired persons in four European countries, selected using quota sampling. A total of 4160 subjects aged 65 years or older were selected. This cross-sectional study was carried out using an internet questionnaire sent to the selected individuals in France $(n=1000)$, Belgium $(n=1076)$, Italy $(n$ $=1081)$ and Germany $(n=1003)$. The survey was based on quota sampling to achieve a sample 
representative of the general population. The reference population selected was diverse in terms of age, including both recently retired persons as well as oldest-old individuals. The characteristics used for the quota sampling method were sex, age, socio-professional category, region, city size, number of persons in

the household, autonomy (dependent/independent), marital status, place of residence, income and highest educational qualification. The quotas were defined based on the socio-demographic structure of the population. The aims of the survey were also to obtain useful information about the different subgroups of the population (according to age, sex, income etc.).

\section{The Ipsos ${ }^{\odot}$ Access Panel}

The questionnaires were administered via the Access Panel online service belonging to Ipsos Interactive Services $^{\mathcal{C}}$. The Access Panel is a pool of households and individuals spread homogeneously across the whole country and who regularly accept to participate in market research studies. The panel comprises over 600,000 individuals on whom detailed information has been collected in addition to the data used to establish the quotas (e.g. the size of the household, income, level of education, number of children etc.). This methodology guarantees adequate representativeness for almost all quotas (i.e. sex, age, socioprofessional category, city size and region). Numerous quality controls were carried out at all stages of the survey. Data can be accessed to corresponding authors.

\section{Quality control procedures}

Quality control procedures were implemented at each stage of data collection and all the online sessions were performed using the CONFIRMIT software. This system enables automatic management of how the questionnaire scrolls (guides, filters), eliminates coding errors (e.g. the system does not allow two answers to be given for a question where only one answer is required), displays questions or subquestions in random order to avoid bias linked to the order of appearance of the items on the questionnaire, controls coherence between responses, and ensures automated control of quotas in real time. This software meets ISO 9001 certification standards (2008 version).

\section{Development of the questionnaire}

The questionnaire was developed jointly by the Korian Foundation for Ageing Well, by $\operatorname{IPSOS}^{\mathcal{C}}$, and by a sociologist. The questionnaires contains 25 question units. The topics addressed include concepts related to attachment to the home environment. A number of sociodemographic characteristics were also recorded (age, sex, household, income, marital status, level of education).

\section{Statistical analysis}


For descriptive analysis, qualitative variables were presented as absolute frequencies with percentages. Questionnaire results were analysed using a Principal Components Analysis (PCA). Clusters of residents were identified with the PCA.

\section{Results}

The study population comprised 4160 individuals from Germany, Belgium, France, and Italy. The characteristics of the study population are described in Table 1. Overall, 2389 (57\%) were women; 1414 (34\%) were aged 65 to 69 , and 2709 (65\%) were living maritally. A majority $(2938,70 \%)$ were home owners, while 1253 (30\%) showed signs of social precariousness including low income, and 1159 (27\%) had a low level of education.

A Principal Components Analysis was performed based on questions 1,7, 8, 10, 14, 19, 34, 36 as active variables, while socio-demographic variables and questions $1,3,7,8,10,11,14,19,21,24,25,33,34,35$, $36,37,38$ were used as illustrative variables. The Principal Components Analysis identified six welldefined groups whose main characteristics are described below and in Table 2:

Group $1(\mathrm{~N}=994 ; 23 \%)$ : Mainly Belgian, well-off males with a high level of education. They are fond of their lodgings, furniture and personal belongings. They enjoy life and are confident in the future. This first group mainly prefers to stay at home, adapting their residence to meet their evolving needs rather than sharing accommodation with others.

Group $2(\mathrm{~N}=786 ; 19 \%)$ : Belgians and Germans, single, flexible and young. Their satisfaction with, and fondness for their residence are of lesser magnitude than in Group 1. They are willing to move to accommodation that is more suitable for their physical capacity. This group is also characterised by loneliness, and less contact with those around them. This prompts some people to start a new life, seek to please, and engage in romantic relationships. They are less confident in the future due to a more pronounced anticipation of future dependency.

Group $3(\mathrm{~N}=1014,24 \%)$ : Mainly German and well-off, with well-developed social fabric, living maritally and able to rely on their children. They are happy and satisfied, both physically and mentally. They feel younger than their age. They are independent and life is a pleasure to them. As in Group 1, they are fond of their home, their furniture and their habits. This explains their preference to adapt their current accommodation to their changing needs rather than moving house.

Group $4(\mathrm{~N}=187,5 \%)$ : Mainly German with low income, young, and fragile in both social and human terms, these elderly people cannot rely on their spouse. They are not fulfilled, either mentally or physically. Life is a source of pleasure for only $65 \%$ of this group, compared to $78 \%$ on average. In this group, income was lower than average. They were often in rented accommodation, and less attached to their residence and their habits. Consequently, they were willing to change accommodation if it will mean better living conditions, and $50 \%$ of them would envision living in a nursing home. 
Group $5(\mathrm{~N}=470,25 \%)$ : Of Italian origin, socially isolated, female, elderly. They have limited financial resources and a low level of education. They suffer from social precariousness, with few friends on whom they can count, and also physical problems that render them dependent (48\%). The majority of those in this group do not consider life to be a source of pleasure, and they have less confidence in the future. They would be willing to move house and region for an accommodation that is more suited to their physical state, because they feel little attachment to their furniture, personal belongings and daily habits.

Group $6(\mathrm{~N}=709,17 \%)$ : Mainly Italian, mainly fond of their residence, predominantly women $(72 \%)$. This group presents some similarities with Group 5, in that they are dependent and isolated. The elderly in this group do not feel physically and mentally fulfilled. They cannot save money due to their relatively low income. Only $38 \%$ of them feel confident in the future. Contrarily to the isolated Italians in Group 5, those in Group 6 are very attached to their habits, their furniture and their home, and consequently, are not willing to move.

The profiles of French respondents were neutral, and did not belong to any of the six well-distinguished groups identified above.

The profiles of European elders are presented in Figure 1.

\section{Discussion}

We show that there are different typologies regarding the perception of one's home according to geographic location. Indeed, the profile of young, recently-retired elders, living maritally, independent and fond of their routine, is more pronounced among the Belgian and Germany respondents. These groups prefer to adapt their accommodation to their changing needs rather than live in a nursing home. This finding is in line with a report showing that people with high cultural capital, and usually also high economic capital, with solid and active family networks, try to control their ageing in an adapted environment. German respondents who had a more precarious social situation than their wealthier counterparts, had fewer social links, and their attachment to material belongings and their accommodation was low. They show a tendency to move house or live in a nursing home if it means that the living conditions are better. Moving into a nursing home can be a strategy to combat loneliness (31).

The Italians are represented by two socially insecure profiles: the first comprises mainly socially-oriented individuals who are very fond of their home. Despite difficult living conditions, they prefer to remain at home rather than to live in a nursing home. The second profile comprised essentially isolated individuals with few social contacts. For these individuals entry into a nursing home can be a solution to achieve a better quality of life. Finally, the French are represented by balanced profiles that are not dominated by any one group or class of individuals.

Our results are coherent with previous data published in the literature. Social isolation and loneliness can lead physically able-bodied elderly persons to seek out collective living arrangements, such as assisted 
living. Our study also reveals geographical specificities, which may be at least partially explained by different policies regarding care of elders in society between countries in the North versus the South of Europe. In southern European countries such as Italy, the fate of incapacitated elderly people depends on the family rather than on institutional solidarity, in contrast with northern countries like Germany or Belgium. These findings can be interpreted as evidence that culture and socio-economic factors can influence the elders' perception of their place of residence, which could result in different emotional responses when a change of place of residence is needed. More research is needed, however, to ascertain if the identified profiles can predict adverse outcomes surrounding the transfer to a nursing home.

Our findings also show that living maritally, which was more frequent among Belgian and German elders, contributed to a happier and more fulfilling life both mentally and physically. These results are coherent with previous reports that couples are better equipped to deal with household chores than a single person. Furthermore, in case of dependency, the spouse is usually the primary caregiver, thus delaying or altogether avoiding the need for entry into long-term care.

\section{Strengths and Limitations of the study}

Our study population comprised a sample of individuals recruited by a poll institute in four European countries, and is likely not fully representative of the whole European population of persons aged over 65 years. However, our approach is innovative, and enables analysis of the different components that underpin the perception of the place of residence in the elderly.

\section{Conclusions And Implications}

Entry into a nursing home is often experienced as a profound rupture, and this transition should be guided and anticipated. Understanding the representations that elderly Europeans have of their home makes it possible to define profiles that can serve as a basis for recommendations that will help newly arriving elders to better accept and integrate their new life in the nursing home. Other factors also play an important role in a person's ability to construct a new "home" for themselves in a nursing home. The welcome that is extended to new residents, and the understanding shown by professionals of the psychological factors at stake can create a more empathic attitude and help to improve integration.

\section{Availability Of Data And Materials}

The datasets used and/or analysed during the current study are available from the corresponding author on reasonable request.

\section{Abbreviations \\ $\mathrm{SOC}$}


Selection Optimization and Compensation

\section{References}

1. Foley DJ, Ostfeld AM, Branch LG, Wallace RB, McGloin J, Cornoni-Huntley JC. The risk of nursing home admission in three communities. J Aging Health. 1992 May;4(2):155-73.

2. Himes CL, Wagner GG, Wolf DA, Aykan H, Dougherty DD. Nursing home entry in Germany and the United States. J Cross-Cult Gerontol. 2000;15(2):99-118.

3. Cohen MA, Tell EJ, Wallack SS. Client-related risk factors of nursing home entry among elderly adults. J Gerontol. 1986 Nov;41(6):785-92.

4. Coward RT, Netzer JK, Mullens RA. Residential Differences in the Incidence of Nursing Home Admissions across a Six-Year Period. J Gerontol Ser B. 1996 Sep 1;51B(5):S258-67.

5. Freedman VA. Family structure and the risk of nursing home admission. J Gerontol B Psychol Sci Soc Sci. 1996 Mar;51(2):S61-69.

6. Steinbach U. Social networks, institutionalization, and mortality among elderly people in the United States. J Gerontol. 1992 Jul;47(4):S183-190.

7. Pearlman DN, Crown WH. Alternative sources of social support and their impacts on institutional risk. The Gerontologist. 1992 Aug;32(4):527-35.

8. Stern Y, Tang M-X, Albert MS, Brandt J, Jacobs DM, Bell K, et al. Predicting Time to Nursing Home Care and Death in Individuals With Alzheimer Disease. JAMA. 1997 Mar 12;277(10):806-12.

9. Gaugler JE, Kane RL, Kane RA, Clay T, Newcomer R. Caregiving and institutionalization of cognitively impaired older people: utilizing dynamic predictors of change. The Gerontologist. 2003 Apr;43(2):219-29.

10. Branch LG, Jette AM. A prospective study of long-term care institutionalization among the aged. Am J Public Health. 1982 Dec;72(12):1373-9.

11. Bharucha AJ, Pandav R, Shen C, Dodge HH, Ganguli M. Predictors of nursing facility admission: a 12year epidemiological study in the United States. J Am Geriatr Soc. 2004 Mar;52(3):434-9.

12. Soto ME, Andrieu S, Gillette-Guyonnet S, Cantet C, Nourhashemi F, Vellas B. Risk factors for functional decline and institutionalisation among community-dwelling older adults with mild to severe Alzheimer's disease: one year of follow-up. Age Ageing. 2006 May 1;35(3):308-10.

13. Duée $M$, Rebillard $C$. Santé et protection sociale. La dépendance des personnes âgées: une projection en 2040. In: INSEE, editor. Données sociales - La société française. Paris: INSEE; 2006. 613-619.

14. Dramé M, Fierobe F, Lang P-O, Jolly D, Boyer F, Mahmoudi R, et al. Predictors of institution admission in the year following acute hospitalisation of elderly people. J Nutr Health Aging. 2011 May;15(5):399-403.

15. Blanchet D, Debrand T, Dourgnon P, et al. Santé, vieillissement et retraite en Europe. Econ Stat. 2007; (403-404):3-18. 
16. Henrard J-C. Le dispositif institutionnel d'aide et de soins aux personnes âgées. Bull Epidémiologique Hebd. 2006;(5-6):45-7.

17. Lindrooth RC, Hoerger TJ, Norton EC. Expectations among the elderly about nursing home entry. Health Serv Res. 2000 Dec;35(5 Pt 2):1181-202.

18. Gaugler JE, Duval S, Anderson KA, Kane RL. Predicting nursing home admission in the U.S: a metaanalysis. BMC Geriatr. 2007 Jun 19;7(1):13.

19. Hirono N, Tsukamoto N, Inoue M, Moriwaki Y, Mori E. [Predictors of long-term institutionalization in patients with Alzheimer's disease: role of caregiver burden]. No To Shinkei. 2002 Sep;54(9):812-8.

20. Yaffe K, Fox P, Newcomer R, Sands L, Lindquist K, Dane K, et al. Patient and caregiver characteristics and nursing home placement in patients with dementia. JAMA. 2002 Apr 24;287(16):2090-7.

21. Thoma-Lürken T, Bleijlevens MHC, Lexis MAS, de Witte LP, Hamers JPH. Facilitating aging in place: A qualitative study of practical problems preventing people with dementia from living at home. Geriatr Nurs N Y N. 2018 Feb;39(1):29-38.

22. Schulz R, Belle SH, Czaja SJ, McGinnis KA, Stevens A, Zhang S. Long-term Care Placement of Dementia Patients and Caregiver Health and Well-being. JAMA. 2004 Aug 25;292(8):961-7.

23. Digital technology to enable aging in place. Exp Gerontol. 2017 Feb 1;88:25-31.

24. Harris Y, Cooper JK. Depressive symptoms in older people predict nursing home admission. J Am Geriatr Soc. 2006 Apr;54(4):593-7.

25. Liu K, McBride T, Coughlin T. Risk of entering nursing homes for long versus short stays. Med Care. 1994 Apr;32(4):315-27.

26. Yamamoto-Mitani N, Aneshensel CS, Levy-Storms L. Patterns of family visiting with institutionalized elders: the case of dementia. J Gerontol B Psychol Sci Soc Sci. 2002 Jul;57(4):S234-246.

27. Rowe JW, Kahn RL. Human aging: usual and successful. Science. 1987 Jul 10;237(4811):143-9.

28. Baltes PB, Baltes MM. Psychological perspectives on successful aging: the model of selective optimisation with compensation. In: Baltes. PB, Baltes MM, editors. Successful aging: perspectives from the behavioural sciences. New York, NY, US: Cambridge University Press; 1990.

29. Baltes MM, Carstensen LL. The Process of Successful Ageing. Ageing Soc. 1996 Jul;16(4):397-422.

30. Dahany M-M, Dramé M, Mahmoudi R, Novella J-L, Ciocan D, Kanagaratnam L, et al. Factors associated with successful aging in persons aged 65 to 75 years. Eur Geriatr Med. 2014 Dec;5(6):365-70.

31. Geller J, Janson P, McGovern E, Valdini A. Loneliness as a predictor of hospital emergency department use. J Fam Pract. 1999 Oct;48(10):801-4.

\section{Declarations}

\section{Acknowledgements}

none. 


\section{Funding}

There is no funding to declare.

\section{Author information}

\section{Jan Chrusciel, MD, MPH,}

Public Health Physician, Address: Hôpitaux Champagne Sud, Pôle Information Médicale Evaluation Performance, 101 Av Anatole France 10000 Troyes, F-10000, France ;Phone: 003325494801 / E-mail: jan.chrusciel.md@gmail.com

\section{Sofiane Zid, MD,}

Public Health Physician, Address: Hôpitaux Champagne Sud, Pôle Information Médicale Evaluation Performance, 101 Av Anatole France 10000 Troyes, F-10000, France ;Phone: 003325494801 / E-mail : med.sofianezid@gmail.comAude Letty MSc, CEO of Fondiation Korian pour le Bien VieillirAddress: Fondation Korian pour le Bien Vieillir, 25 rue Balzac, Paris, F-75008 France. / Phone: 00331553752 00,/ E-mail: aude.letty@korian.comPaul Emile Hay MD, Medical Director of Fondiation Korian pour le Bien VieillirAddress: Fondation Korian pour le Bien Vieillir, 25 rue Balzac, Paris, F-75008 France. / Phone: 00331553752 00,/ E-mail: paul-emile.hay@korian.fr

\section{Didier Armaingaud, MD,}

Medical Director of Korian Address: Fondation Korian pour le Bien Vieillir, 25 rue Balzac, Paris, F-75008 France. / Phone: 00331553752 00,/ E-mail: didier.armaingaud@korian.com

\section{Moustapha Dramé MD, PhD,}

Professor of Public Health

Address: Centre Hospitalo-Universitaire de Martinique, CIC 1424 Antilles Guyane, Unité de soutien méthodologique, F-97261 Fort-de-France Cedex, France / Phone: 00333596552000 / E-mail: moustapha.drame@chu-martinique.fr

\section{Lidvine Godaert MD, PhD,}

Physician in geriatry Address: Centre Hospitalo-Universitaire de Martinique, Pôle de Gériatrie Gérontologie, F-97261 Fort-deFrance Cedex, France / Phone: 00333596552000 / E-mail: Iidvine-michele.godaert- simon@chu- 
martinique.fr

\section{Stéphane Sanchez, MD, MPH, (Corresponding author)}

Public Health Physician, Address: Hôpitaux Champagne Sud, Pôle Information Médicale Evaluation Performance, 101 Av Anatole France 10000 Troyes, F-10000, France ;Phone: 003325494801 / E-mail: stephane.sanchez@ch-troyes.fr

\section{Affiliations:}

Dr Jan Chrusciel MD ${ }^{a}$, Dr Sofiane Zid MD ${ }^{a}$, Aude Letty MSc ${ }^{b}$, Dr Paul Emile Hay MD ${ }^{b}$, Dr Didier Armaingaud MD ${ }^{b}$, Pr Moustapha Dramé MD, PhD ${ }^{c}$, Dr Lidvine Godaert MD, PhD d, Dr Stéphane Sanchez $\mathrm{MD}, \mathrm{MPH}^{\mathrm{a}, \mathrm{b}}$

a Hôpitaux Champagne Sud, Pôle Information Médicale Evaluation Performance, Troyes, F-10000, France. ${ }^{b}$ Fondation Korian pour le Bien Vieillir, Paris, F-75008 France. ${ }^{c} \mathrm{CHU}$ de Martinique, CIC 1424 Antilles Guyane, Fort de France, F-97200, France. ${ }^{d}$ CHU de Martinique, Pôle de Gériatrie Gérontologie, Fort de France, F-97200, France

\section{Contributions}

SS, conceived the study idea and design in collaboration with JC, SZ, and AL. SS performed the statistical analyses and wrote the first draft of the manuscript; JC, SZ, AL, PEH, DA, MD, LG and SS contributed to the interpretation of the results and writing of the mansuscript. All authors approved the final version for submission.

\section{Corresponding author}

Correspondence to S. Sanchez.

\section{Ethics declarations}

\section{Ethics approval and consent to participate}

All legal conditions for surveys were respected, and the French national commission governing the application of data privacy laws (the "Commission Nationale Informatique et Libertés") issued approval for both projects. Since the study was strictly observational and used anonymous data, in accordance to the laws that regulate "non-interventional clinical research" in France, namely articles L.1121-1 and 
R.1121-2 of the Public Health Code, did not require the written informed consent from the participants or the authorization from any other ethics committee to conduct this survey.

\section{Consent for publication}

Not applicable

\section{Competing interests}

The authors declare that they have no competing interests.

\section{Tables}

Table 1: Characteristics of the study population 


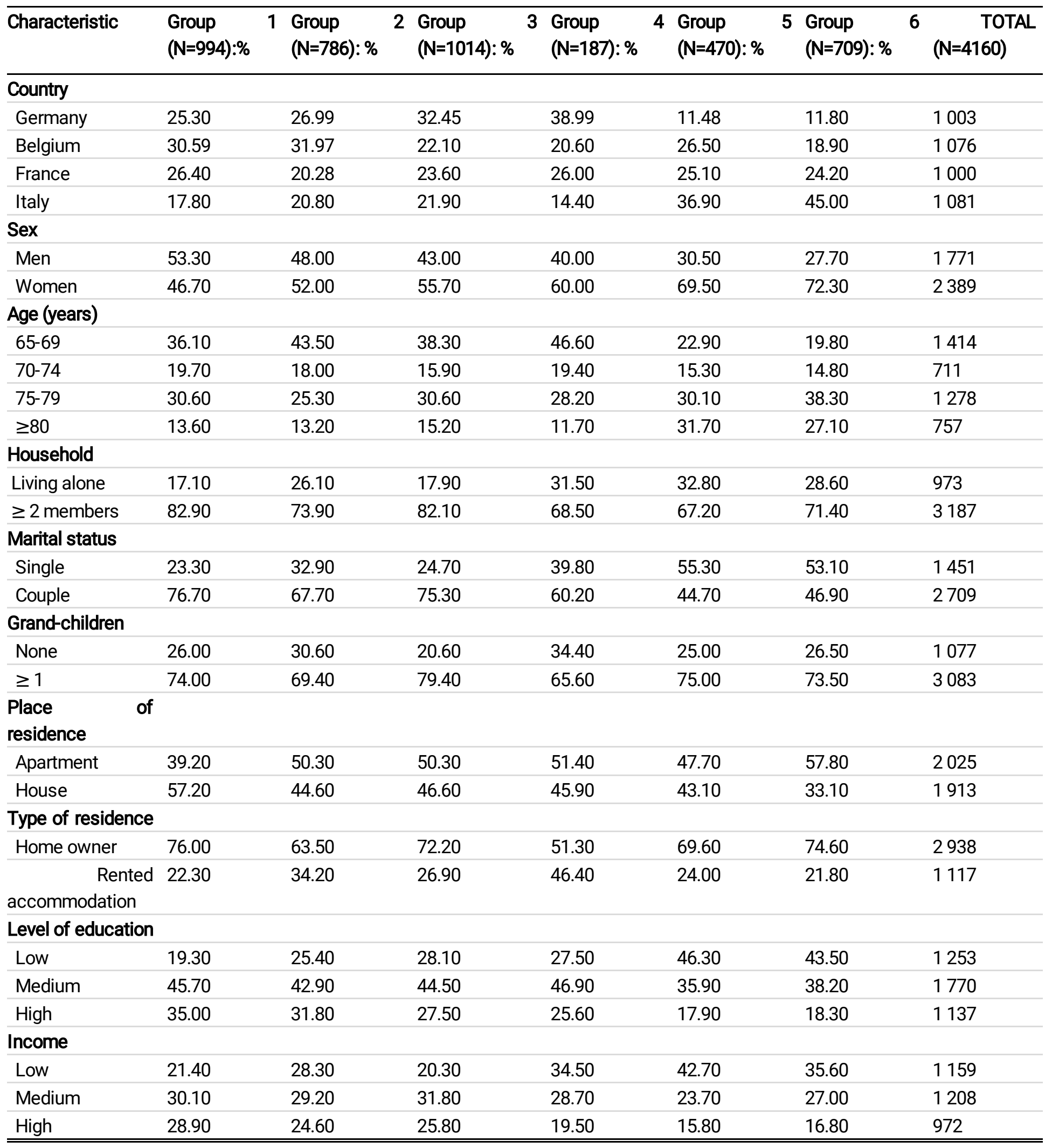

Table 2: Characteristics of the different profiles identified by principal component analysis 


\begin{tabular}{|c|c|c|}
\hline \multicolumn{3}{|l|}{1 : Wealthy Belgians } \\
\hline of their current residence & 96.02 & 90.13 \\
\hline :ally and mentally fufilled & 79.61 & 67.79 \\
\hline $\mathrm{n}$ their spouse & 70.40 & 59.53 \\
\hline to have fun & 59.58 & 50.16 \\
\hline lent in the future & 53.03 & 50.04 \\
\hline רcome & 28.90 & 23.68 \\
\hline əvel of education & 34.97 & 27.33 \\
\hline d accommodation with other people & 2.37 & 10.30 \\
\hline and adapt current accommodation & 78.95 & 69.25 \\
\hline ff furniture and personal belongings & 47.29 & 40.66 \\
\hline sex & 53.29 & 42.58 \\
\hline $\mathrm{n}$ & 30.59 & 25.89 \\
\hline \multicolumn{3}{|l|}{ 2: Flexible single people } \\
\hline $\bar{j}-69$ years & 43.50 & 33.97 \\
\hline I new life & 53.81 & 32.19 \\
\hline please people & 48.37 & 27.88 \\
\hline ntic feelings & 67.40 & 44.86 \\
\hline have fun & 81.51 & 67.24 \\
\hline $\mathrm{g}$ of loneliness & 46.51 & 32.51 \\
\hline ff current accommodation & 84.06 & 90.13 \\
\hline led with current accommodation & 53.64 & 71.63 \\
\hline and adapt current accommodation & 55.70 & 59.25 \\
\hline Ied to their habits & 60.73 & 37.28 \\
\hline of furniture and personal belongings & 52.54 & 40.66 \\
\hline ize outings more often & 73.63 & 64.48 \\
\hline ely on the neighbours & 55.02 & 50.84 \\
\hline sating old age & 80.51 & 75.79 \\
\hline lent in the future & 56.87 & 50.04 \\
\hline to new accommodation more suited to physical state & 53.01 & 34.35 \\
\hline e sex & 51.98 & 57.42 \\
\hline an & 27.00 & 24.11 \\
\hline \multicolumn{3}{|l|}{ 3: Wealthy Germans } \\
\hline an & 32.45 & 24.11 \\
\hline led with current accommodation & 90.10 & 71.63 \\
\hline Ied to their habits & 72.73 & 48.32 \\
\hline ff furniture and personal belongings & 60.31 & 35.43 \\
\hline and adapt current accommodation & 81.84 & 69.25 \\
\hline , high opinion of their current accommodation & 85.35 & 76.15 \\
\hline a source of pleasure & 94.13 & 78.24 \\
\hline :ally and mentally fufilled & 84.07 & 67.97 \\
\hline ounger than their age & 78.24 & 62.10 \\
\hline going out to restaurants & 81.24 & 68.27 \\
\hline maritally (couple) & 75.34 & 65.11 \\
\hline
\end{tabular}


endent

$\mathrm{n}$ their children

ave money

\section{4 : Low-income Germans}

$s$ to their current accommodation

d accommodation

Ied to the advantages offered by their accommodation

led to their habits

If furniture and personal belongings

led with current accommodation

to live in another region

to live closer to facilities/services

it imagine living in a nursing home

$\mathrm{n}$ their spouse

ately mentally and physically fulfilled

a source of pleasure

nily gatherings

anticipate old age

ıcome

ave money

an

\section{5 : Isolated Italians}

al confidence in the future

entally and physically fulfilled

from loneliness at times

to smaller accommodation that they really like

to new accommodation more suited to physical state

to an assisted living apartment

ff furniture and personal belongings

led to their habits

ely on their friends

atisfaction with current accommodation

endent

Icome

!vel of education

$v(\mathrm{er})$

80 years

\section{5: Italian homebirds}

ately mentally and physically fulfilled

e sex

j-79 years

maritally (Couple)

$\mathrm{n}$ their spouse

fond of their current accommodation

Ied to their habits
78.23

82.28

83.05

54.78

77.03

46.35

11.28

8.15

6.74

56.05

44.65

47.16

49.57

24.51

40.89

65.67

44.55

40.18

34.46

22.87

38.99

64.40

61.16

42.09

46.69

40.02

46.83

42.61

52.60

52.59

52.41

42.73

46.23

41.03

31.67

36.90

41.80

72.28

38.33

46.94

39.52

96.94

79.58
73.02

71.17

44.98
9.86

26.86

35.17

37.28

40.66

71.64

21.33

30.67

37.00

18.63

32.19

78.24

21.65

24.20

27.87

40.82

24.11

49.86

32.19

23.37

29.23

34.35

28.32

40.66

37.28

33.57

28.36

73.02

27.87

30.13

21.38

18.20

25.98 


\begin{tabular}{lll} 
If furniture and personal belongings & 57.91 & 35.42 \\
\hline to new accommodation more suited to physical state & 28.20 & 34.35 \\
\hline ave money & 36.80 & 40.82 \\
\hline Jate old age & 69.28 & 75.79 \\
\hline lent in the future & 38.53 & 50.04 \\
\hline כndent & 60.96 & 73.02 \\
\hline Icome & 35.59 & 27.87 \\
\hline
\end{tabular}

\section{Figures}

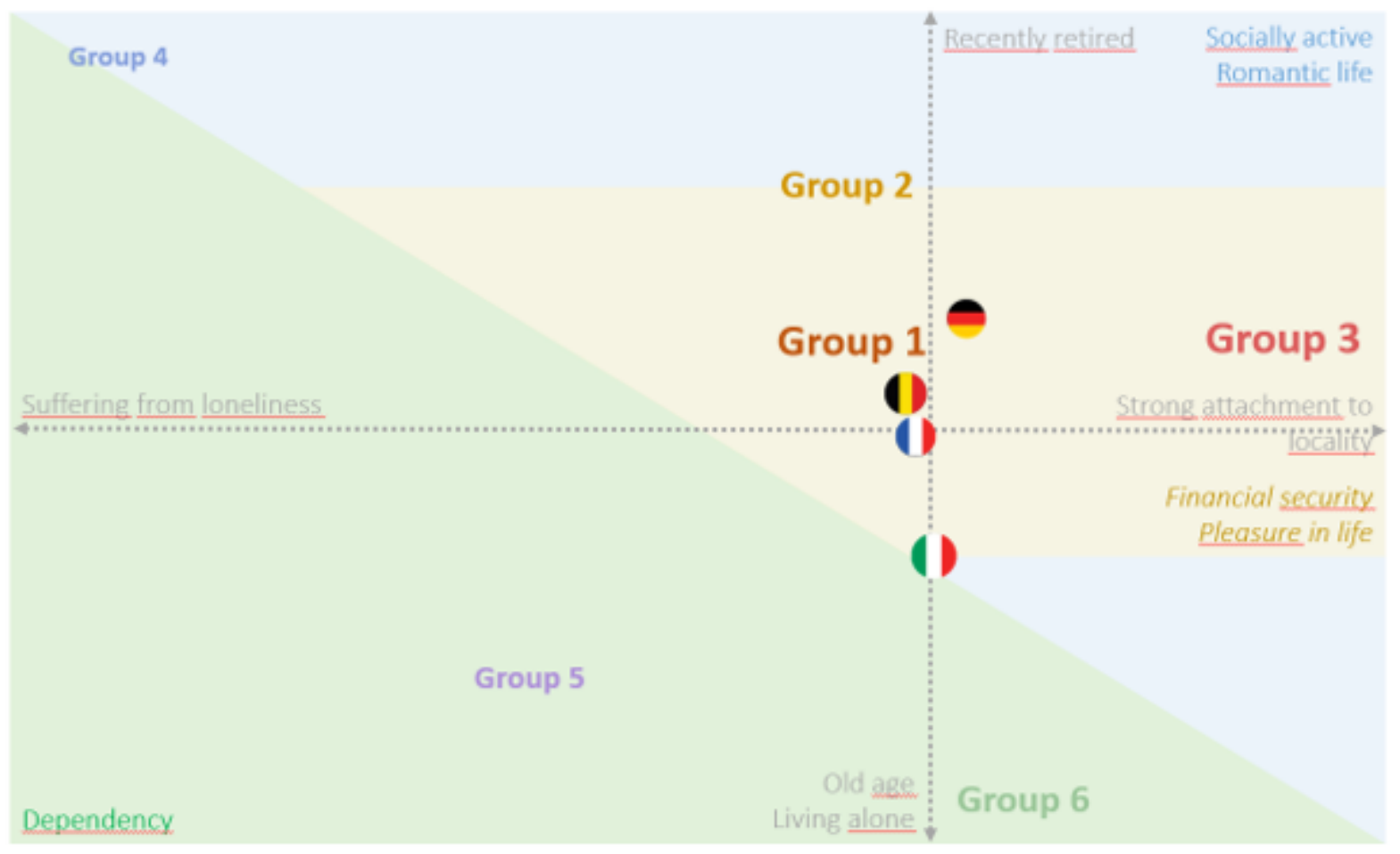

\section{Figure 1}

Categories identified by principal components analysis, by country. Profiles of European elders identified by principal components analysis. 